\title{
Fiscal Convergence and Total Factor Productivity: Firm-Level Evidence from Pakistan
}

\author{
Usman Shaukat KHAN ${ }^{1}$, Muhammad Arshad KHAN ${ }^{2}$, Saima NAWAZ ${ }^{3}$, Abdul RAHMAN ${ }^{4}$
}

Received: July 20, 2020 Revised: September 06, 2020 Accepted: September 10, 2020

\begin{abstract}
This study examines the impact of corporate tax, a fiscal measure along with trade liberalization and research and development on total factor productivity for a panel of 153 industrial firms listed on the Pakistan Stock Exchange over the period 1997-2017. For empirical analysis, we employ the system generalized method of moment estimator. In the first step, we estimate industrial production function and the results reveal that raw material, industrial labour force and energy play vital role in enhancing industrial production. Whereas, industrial capital exerts negative impact on industrial output. We also measured total factor productivity using the production elasticities. In the second step, we examine the impact of corporate tax, trade liberalization and research and development on total factor productivity. The results indicate that higher level of corporate tax exerts negative impact on total factor productivity. The findings reveal that higher corporate taxation discourages industrial firms to undertake research and development thereby exerting adverse impact on total factor productivity of firms. The impact of trade liberalization proxied by average tariff is positive while customs duty and sales tax negatively impact firm-level total factor productivity. These findings provide useful insights for managers, investors and policy makers in Pakistan.
\end{abstract}

Keywords: Total Factor Productivity, Trade Liberalization, Production Function, Corporate Tax

JEL Classification Code: D21, D22, L25, O3, O4

\section{Introduction}

Industrial sector plays vital role in economic growth of an economy. Kuznets (1966) argued that long-term economic development of a country depends on productivity of the industrial sector which is a key component of modern economic growth. Historically, many countries transitioned

${ }^{1}$ First Author and Corresponding Author. Ph.D. Scholar, Department of Management Sciences, COMSATS University, Islamabad, Pakistan [Postal Address: Park Road, Islamabad, Islamabad Capital Territory, 45550, Pakistan] Email: usmanshaukatkhan@gmail.com

${ }^{2}$ Associate Professor and Chairman, Department of Economics, COMSATS University, Islamabad, Pakistan.

Email: arshad.khan@comsats.edu.pk

${ }^{3}$ Assistant Professor, Department of Economics, COMSATS University, Islamabad, Pakistan.

Email: saima.nawaz@comsats.edu.pk

${ }^{4} \mathrm{Ph}$.D. Scholar, Department of Management Sciences, COMSATS

University, Islamabad. Email: rehmansargodha@yahoo.com

(c) Copyright: The Author(s)

This is an Open Access article distributed under the terms of the Creative Commons Attribution Non-Commercial License (https://creativecommons.org/licenses/by-nc/4.0/) which permits unrestricted non-commercial use, distribution, and reproduction in any medium, provided the original work is properly cited. from developing to developed countries through industrial sector development. For example, China and India being labour intensive countries raised productive capacity of their labor force, which enhanced their industrial output. Many academicians (for example, Abramovitz, 1956; Solow, 1956; Denison, 1962) argued that per capita income growth cannot be solely explained by the factors of production but by the residual called productivity. However, new growth theories assumed that determinants of technological advances are endogenous rather than exogenous (Bournakis\& Mallick, 2018). With the increase in total factor productivity (TFP), output of industrial sector is enhanced that in turn increases the competitiveness in domestic as well as international market.

An economy is mainly governed by two sources of growth, namely input-driven growth and productivitydriven growth. The input-driven growth can be attributed to factors of production while the productivity-driven growth is accredited to improvement in knowledge, technology transfers, information technology and efficient use of factors of production (Young, 1992; Sehgal \& Sharma, 2012). Few studies (for example, Syverson, 2011; Ghosh, 2013) found that TFP of industrial sector is mainly derived from 
technological advancement and improvement in the quality of raw materials. However, Chaudhry (2009) attributed increase in productivity to be input-driven. Thus, it can be argued that TFP is a vital component in the economic growth and social welfare.

The correct estimation of TFP is central in planning and policy making. Hence, economists are cautious for correct calculation of TFP. While analyzing TFP, the productivity shocks also need to be analyzed. These shocks may be positive or negative for the firm(s) and arises as a result of technological change. Firms usually respond to positive productivity shocks by increasing the amount of inputs through expansion in output, while negative productivity shocks decrease firm-level output. In either case, the effect of such shocks is significant because many firms may exit from the industry due to non-adoption of technological innovations.

The identification of appropriate determinants of TFP is vital for accurate policy making. The literature highlighted various determinants of TFP at industrial level, for instance, research and development (R\&D), human capital, investments in information and communication technology (ICT) and international trade (Aghion \&Howit, 2006). Kim, Loayza and Balcazar (2016) classified macro determinants of TFP into four categories namely, innovation, market efficiency, physical infrastructure and institutional infrastructure. The TFP accounts for major part of variations in per capita income across countries (Hall \& Jones, 1999; Hsieh \&Klenow, 2009). Technically, aggregate TFP depends on the firm-level TFP, hence most of the empirical literature focused on measuring productivity effects at aggregate level (Syverson, 2011; Ahmed, Khan, Mahmood, \& Afzal, 2017). Therefore, analysis of TFP is necessary condition for accurate projection of productivity growth.

According to the Global Competitiveness Index Report (2017-18), Pakistan is ranked at $110^{\text {th }}$ in terms of global competition, $105^{\text {th }}$ in terms of infrastructure and $116^{\text {th }}$ in terms of macroeconomic environment. Further, Pakistan is ranked $25^{\text {th }}$ in terms of GDP (PPP) and $41^{\text {st }}$ in terms of nominal GDP. Although, this ranking was better by seven points as compared to 2017, but still Pakistan rank is very low. This dismal position can be attributed to various structural and macroeconomic imbalances such as energy crisis, inflation, fiscal deficit and exchange rate instability. These factors adversely affected the performance of TFP at firm as well as at industry-level. The other reasons of low TFP could be the insufficient availability of quality raw material, lack of credit availability and complex tariff structure that undermine the performance of industrial sector in Pakistan.

The empirical literature highlighted the role of trade liberalization in the productive performance of firms (Bravo-Biosca, Criscuolo\& Menon, 2016). In the context of Pakistan, various studies (for example, Khan \& Qayyum,
2007; Qayyum \& Khan, 2009; Sheikh \& Ahmed, 2011; Khan \& Ahmad, 2012; Zakaria \& Ahmed, 2013; Ahmed, Khan, Mahmood \& Afzal,2017) examined the impact of trade liberalization and trade openness on aggregate industrial productivity. ${ }^{1}$ However, these studies overlooked the role of corporate tax as a tool of fiscal policy in affecting firm-level TFP. It is well recognized that trade liberalization, in terms of tariff concessions has important consequences for developing countries like Pakistan. It creates fiscal imbalance because major portion of government revenue consists of indirect taxes. Consequently, the government imposes corporate taxes to improve the fiscal convergence. Acknowledging the role of fiscal policy in affecting productivity at firm level, this study attempts to investigate the impact of corporate tax, trade liberalization and $R \& D$ on firm-level TFP in case of Pakistan. We hypothesized that higher rate of the corporate tax would bring distortive effect on TFP growth. This argument is drawn based on increasing cost of capital, which in turn discourages firms to invest in R\&D activities (Hall \&Van Reenen, 2000). The higher level of corporate tax increases user cost of capital which may discourage firms in initiating capital investment that uses new equipment (Devereux \& Griffith, 2003). Likewise, Brekke, Garcia, Schindler and Schjelderup (2014) pointed out that higher corporate taxation is linked with moral hazards and asymmetric information between firms and its external creditors.

With reference to Pakistan, existing empirical studies used aggregate production function in estimating TFP. However, we computed firm-level TFP using a variant of Cobb-Douglas production function. The present study estimated firm-level TFP for a panel of 153 industrial firms listed on the Pakistan Stock Exchange (PSX) using Olley and Pakes (1996) methodology which is useful in dealing with the issues of endogeneity and selection bias and thus provides robust estimates. To the best of our knowledge, no study is available with reference to Pakistan that analyzed the impact of corporate tax as fiscal policy measure, trade liberalization and R\&D on firm-level TFP. This study contributes to the existing literature in two ways: Firstly, we estimated firm-level TFP using the industrial production function augmented with raw material and energy inputs in addition to industrial labour and physical capital stock by considering 153 firms over the period 1997-2017. Secondly, we examine the impact of fiscal policy in terms of corporate taxation on TFP in case of Pakistan.

The rest of the paper is organized as follows: Section 2 delineates brief literature review, section 3 elaborates data, research methodology and econometric modeling. Section 4 highlights results and discussions, while section 5 elaborates conclusion, policy implications, limitations and future direction. 
Usman Shaukat KHAN, Muhammad Arshad KHAN, Saima NAWAZ, Abdul RAHMAN /

\section{Literature Review}

The origins of productivity can be traced back to the seminal work of Solow (1956) who defined productivity as a residual in the production function. Solow (1956) argued that TFP growth is vital for sustainable development of a country through innovations and technological transformation. A large number of studies (inter alia by Fulginiti, Perrin \& Yu, 2004; Hall \& Scobie, 2006; Biesebroeck, 2007; Katayama, Lu,\& Tybout, 2009; Eberhardt \& Christian, 2010; Del Gatto, Liberto, \& Petragliam 2011; Van Beveren, 2012) estimated TFP at aggregate level using the Ordinary Least Square (OLS), Fixed Effects (FE) and Random Effects (RE) models. However, inferences based on these approaches are biased due to the problem of simultaneity, endogeneity and sample selection. To address these problems, Olley and Pakes (1996) developed an alternative methodology by estimating the production function using investment function as a proxy for unobserved productivity shocks. Few studies modified Olley and Pakes (1996) methodology by incorporating the intermediate inputs as proxy for unobserved productivity shocks (for instance, Pavcnik, 2002; Levinsohn \& Petrin, 2003; Fernandes, 2007; Konings \& Vandenbussche, 2013; Javorcik \& Spatareanu, 2008; Ackerberg, Caves,\& Frazer, 2015; Ahmed, Khan, Mahmood, \& Afzal, 2017; Bournakis \& Mallick, 2018).

Van Biesebroeck (2007) compares five main approaches used in TFP estimation namely Index Number, Data Envelopment Analysis, Stochastic Frontier, GMM estimator and Semi-parametric estimation using simulated data. However, the author viewed GMM estimator as the most robust estimation technique in the presence of measurement error and technological heterogeneity across firms. Likewise, DelGatto, Liberto, and Petragliam (2011) reviewed methods of TFP measurement and classified them into three categories viz-a-viz deterministic, parametric and non-parametric approaches. They concluded that semi-parametric approach is more appropriate for analyzing micro-level data.

Based on the micro-level data, Melitz (2003) found that differences in firm-level TFP underscore the new international trade theory which is based on heterogeneity. On the other hand, Bloom and Van Reenen (2010) examined the impact of quality of managers and labor force on TFP and found that learning process is firm-specific with positive impact on firmlevel TFP. Firm's characteristics are considered as another important determinant of TFP. Kim, Loayza, and Balcazar (2016) argued that large firms can outperform smaller firms due to differential level of economies of scale. Likewise, few studies also found positive relationship between trade and firm's productivity (Eaton, Kortum \& Kramarz, 2011; Kasahara \& Lapham, 2013).

With reference to Pakistan few studies (for example, Burki\& Khan, 2004; Khan, 2006; Ahmed, Khan,
Mahmood,\& Afzal, 2017) focused on macroeconomic determinants of TFP at the aggregate level. While studying TFP of manufacturing sector, Ahmed, Khan, Mahmood, and Afzal (2017) considered trade barriers such as effective rate of protection, domestic investment and regulatory levies and excise duties as determinants in Pakistan. They concluded that TFP and economic growth moves in the same direction. On the other hand, Chaudhry (2009) analyzed the performance of manufacturing sector by estimating TFP of large-scale manufacturing for agriculture sector and found that growth in this sector was input-driven rather than productivity-driven. However, one of the consequences of trade liberalization in terms of tariff reduction is the loss of government revenue in developing countries like Pakistan, which may create fiscal imbalance. In this scenario, imposition of corporate tax can help to improve fiscal imbalance. Hence, the present study incorporated corporate tax as a fiscal policy measure to analyze its impact on firm-level TFP.

Empirically few studies (see Djankov, Ganser, McLiesh, Ramalho, \& Shleifer, 2010; Bournakis \& Mallick, 2018) found that the higher corporate tax exerted distortive effects on TFP growth. They argued that imposition of corporate tax increases the user cost of capital leaving the firms with lower amount of after-tax profits for long-run growth. Thus, firm's ability to make decisions on capital investment weakens due to lower profits. Lucas (1990) argued that corporate tax should not be imposed because corporate profits are the main source of firm's long-run investment and growth. The literature identifies two distinct views on corporate tax-TFP nexus. The first view suggested that an increase in corporate tax rate would affect firm's investment ability due to high cost of capital (Fullerton, 1987; Gentry \& Glenn, 1998; Devereux \& Griffith, 2003). The high cost of capital seems to be disincentive for gaining higher profits through increased TFP by using new technology. The second view links corporate tax, moral hazard and asymmetric information with firm's internal and external creditors (Brekke, Garcia, Schindler, \& Schjelderup, 2014; Bournakis\& Mallick, 2018).

With regards to the R\&D and TFP nexus, Manez, Rochina-Barrachina, Sanchis-Lopis, and Vicente (2014) argued that $\mathrm{R} \& \mathrm{D}$ firms and exporting firms have higher degree of risk. R\&D firms facing high degree of uncertainty due to sunk costs require higher amount for financing. Likewise, Dischinger and Nadine (2011) found that firms choose those geographical regions for market exploration where corporate tax rate is lower but have higher consumer tax. Likewise, Gorg and Spaliara (2014) found that exporting firms have higher costs as compared to non-exporting firms due to new markets and transportation networks, hence such firms require extra financial resources. High corporate tax rate discourages R\&D activities, resultantly TFP decreases which undermine firm's performance. 
To the best of our knowledge, no study is available that examined the impact of corporate tax, trade liberalization and R\&D on firm-level TFP in Pakistan. Therefore, this study considerably contributes to empirical literature by studying the above cited linkages on the industrial sector in Pakistan.

\section{Research Methods and Materials}

\subsection{Data Description}

The present study uses panel data of 153 industrial firms listed at the Pakistan Stock Exchange (PSX) for the period 1997-2017 to examine the impact of corporate tax, trade liberalization and R\&D on TFP. We have used unbalanced panel because the time periods available for some variables vary from firm to firm. One major advantage of using unbalanced panel data is that it allows exploiting a larger sample and may lessen the impact of self-selection of individual firm in the sample. Hsiao (2003) argued that observations in the initial cross-sectional units are independently distributed and the subsequent addition and deletion take place at random under unbalanced panels. The data is collected from various sources, such as the Audited Annual Accounts of Industrial Firms, PSX, Federal Board of Revenue (FBR) and Pakistan Bureau of Statistics (PBS). Missing data were interpolated using linear interpolation technique.

\subsection{Definition of Variables}

We used total sales (Y) as a proxy for industrial output of each firm (sum of local sales and exports) as dependent variable whereas, physical capital stock (K), labor force (L), raw material (RM) and energy (EN) are used as dependent variables for estimating the firm-level industrial production function. Physical capital stock is calculated as the sum of property, plant and equipment held by firms, whereas labor force is taken as direct workforce involved in the production process. The energy includes electricity and gas charges associated with production process. These variables are deflated by wholesale price index (WPI) to capture the effects of price changes. We examine the impact of corporate tax rate (CRT), trade liberalization (TL) and R\&D on firm-level TFP. Corporate tax rate is the tax imposed by the government on corporate profits, while trade liberalization (TL) is tariff concessions proxied by average tariff rate (AVT), customs duty (CD) and sales tax (ST). Whereas, R\&D is dichotomous variable and assigned 1 if firms have invested in R\&D and 0 otherwise.

\subsection{Research Method}

We start with the estimation of industrial production function and TFP for a panel of 153 industrial firms in
Pakistan. Following Alimi (2015), Ahmed, Khan, Mahmood and Afzal (2017) and Bournakis and Mallick (2018), we specify the following industrial production function:

$$
Y_{i t}=A_{i t} K_{i t}^{\alpha} L_{i t}^{\beta} R M_{i t}^{\gamma} E N_{i t}^{\delta}
$$

where $\mathrm{Y}$ is industrial output, $\mathrm{A}$ is total factor productivity, $\mathrm{K}$ is capital stock, $\mathrm{L}$ is labor force engaged in industrial sector, RM is raw material and EN is energy consumption by industrial sector, while i denotes for number of crosssectional units (that is, industries) and t represents time period. The log-linear form of above production function can be expressed as;

$$
Y_{i t}=\ln A_{i t}+\alpha \ln K_{i t}+\beta \ln L_{i t}+\gamma \ln R M_{i t}+\delta \ln E N_{i t}
$$

Following Bournakis and Mallick (2018), we decompose technical efficiency as:

$$
\ln A_{i t}=a_{0}+\omega_{i t}+u_{i t}
$$

Substituting equation (3) into equation (2), we can write equation (4) as:

$$
\begin{aligned}
Y_{i t}=a_{0} & +\alpha \ln K_{i t}+\beta \ln L_{i t}+\gamma \ln R M_{i t}+\delta \ln E N_{i t} \\
& +\omega_{i t}+u_{i t}
\end{aligned}
$$

where $\omega_{i t}$ is unobserved demand shock that affects productivity of $i^{\text {th }}$ firm, $a_{0}$ is firm's average efficiency across all firms, while $u_{i t}$ is error term. We decompose $\omega_{i t}$ into firmspecific effects $\left(\eta_{i}\right)$ and time-specific effects $\left(\lambda_{t}\right)$. Thus, equation (4) can be rewritten as:

$$
y_{i t}=a_{0}+a k_{i t}+\beta l_{i t}+\gamma r m_{i t}+\delta e n_{i t}+\left(\eta_{\mathrm{i}}+\lambda_{\mathrm{t}}\right)+u_{i t}
$$

The lower-case letters represent the logarithmic values of the respective variable. In a more compact form, equation (5) can be written as:

$$
y_{i t}=a_{0}+a k_{i t}+\beta l_{i t}+\gamma r m_{i t}+\delta e n_{i t}+\omega_{i t}+u_{i t}
$$

Estimation of equation (6) by OLS method involved the problem of sample selection bias between industryspecific and time-specific unobserved productivity shocks. This indicates that the variable inputs and $\boldsymbol{\omega}_{\mathrm{it}}$ are correlated causing endogeneity problem. To tackle this problem, Olley and Pakes (1996) used investment function as a proxy for unobserved productivity shocks. However, one major limitation of Olley and Pakes (1996) methodology is that it requires positive investments, therefore, observations with zero or negative investment(s) must be dropped from the data. To overcome this limitation, many researchers (few among others, Fernandes, 2007; Levinsohn \& Petrin, 2003; Ghosh, 
2013; Ahmed, Khan, Mahmood \& Afzal, 2017; Bournakis\& Mallick, 2018) suggested the use of intermediate inputs to proxy for unobserved productivity shocks. Thus, considering the intermediate input demand function, we used raw material as a proxy of unobserved productivity shocks; which is given in equation (7).

$$
r m_{i t}=g\left(\omega_{i t}, k_{i t}\right)
$$

The inverse of raw material demand function expresses productivity shocks as a function of raw material and capital stock, which takes the following form;

$$
\omega_{i t}=g^{-1}\left(r m_{i t}, k_{i t}\right)
$$

Using equation(s) (7) and (8), we can transform equation (6) as;

$$
y_{i t}=a_{0}+a_{\mathrm{k}} k_{i t}+\beta_{\mathrm{l}} l_{i t}+\delta_{\mathrm{en}} e n_{i t}+\phi_{i t}\left(r m_{i t}, k_{i t}\right)+u_{i t}
$$

where

$$
\phi_{i t}\left(r m_{i t}, k_{i t}\right)=a+a k_{i t}+\gamma r m_{i t}+g^{-1}\left(r m_{i t}, k_{i t}\right)
$$

The Olley and Pakes (1996) algorithm is implemented in two steps. In the first step, we generate conditional expectation following Ahmed, Khan, Mahmood and Afzal (2017) of the form;

$$
\begin{aligned}
y_{i t}-E\left(y_{i t} \mid r m_{i t}, k_{i t}\right)=\beta\left(l_{i t}-E\left(l_{i t} \mid r m_{i t}, k_{i t}\right)-\delta\left(e n_{i t}\right.\right. \\
-E\left(l_{i t}, k_{i t}\right)+u_{i t}
\end{aligned}
$$

$\mathrm{E}\left(\mathrm{y}_{i t} \mid \mathrm{rm}_{i t}, \mathrm{k}_{i t}\right), \mathrm{E}\left(1_{i t} \mid \mathrm{rm}_{i t}, \mathrm{k}_{i t}\right)$ and $\mathrm{E}\left(\mathrm{en}_{i t} \mid \mathrm{rm}_{i t}, \mathrm{k}_{i t}\right)$ to compute the estimates of labor and energy $(\hat{\beta}, \hat{\delta})$ at first stage as

$$
\begin{array}{r}
y_{i t}-E\left(y_{i t} \mid r m_{i t}, k_{i t}\right)=\beta\left(l_{i t}-E\left(l_{i t} \mid r m_{i t}, k_{i t}\right)-\delta\left(e n_{i t}\right.\right. \\
\left.-E\left(l_{i t} \mid r m_{i t}, k_{i t}\right)+u_{i t}\right)
\end{array}
$$

and $\left(\omega_{i t} \mid r m_{i t}, k_{i t}\right)=0$, the difference between equation (10) and its conditional expectations on raw material and capital stock is given in equation (11).

We estimate the conditional expectations using GMM estimator which is useful technique in dealing with heteroscedasticity and autocorrelation; we get the consistent estimate of $\phi_{i, t}($.$) by regressing;$

$$
v_{i t}=\left(y_{i t}-\hat{\beta} l_{i t}-\delta e n_{i t}\right) \text { on }\left(r m_{i t}, k_{i t}\right)
$$

In the second stage, we use the GMM estimator following Olley and Pakes (1996) approach to obtain the consistent estimates of $(\alpha, \gamma)$ thus, we assume that estimation of productivity follows the first order Markov process, that is, $\omega_{i, t}=E\left(\omega_{i, t} \mid \omega_{i t-1}\right)+\xi_{i, t}$ where $\xi_{i, t}$ is an idiosyncratic error term of the productivity function (Bournakis \& Mallick, 2018). The estimation involves two moment conditions. The first moment condition states that capital stock at time $t$ is uncorrelated with unexpected productivity shocks at time $t$ and is given by;

$$
\begin{gathered}
E\left[y_{i t}-\beta l_{i t}-\gamma r m_{i t}-\delta e n_{i t}-\alpha k_{i t}-E\left(\omega_{i t} \mid \omega_{i t-1}\right) \mid k_{i t-1}\right] \\
=E\left(u_{i t}+\xi_{i t} \mid k_{i t-1}\right)=0
\end{gathered}
$$

The second moment condition indicates that the raw material at time $t-1$ is uncorrelated with unexpected productivity shocks at time $t$, which is given by;

$$
\begin{aligned}
& \mathrm{E}\left[\mathrm{y}_{i t}-\beta 1_{i t}-\gamma \mathrm{rm}_{i t}-\delta \mathrm{en}_{i t}-\alpha \mathrm{k}_{i t}-\mathrm{E}\left(\omega_{i t} \mid \omega_{i t-1}\right) \mid \mathrm{rm}_{i t}\right] \\
& =\mathrm{E}\left(\mathrm{u}_{i t}+\xi_{i t} \mid \mathrm{rm}_{i t-1}\right)=0
\end{aligned}
$$

where the residual in the moment conditions, $u_{\mathrm{i}, \mathrm{t}}+\xi_{\mathrm{i}, \mathrm{t}}$, are estimatedas;

$$
\left(u_{i t}+\xi_{i t}\right)(\hat{\alpha}, \hat{\gamma})-y_{i t}-\hat{\beta} l_{i t}-\hat{\alpha} k_{i t}-\hat{\gamma} r m_{i t}-E\left(\omega_{i t} \mid \omega_{i t-1}\right)
$$

We start with the following conditional expectation;

$$
E\left(\omega_{i t} \mid \omega_{i t-1}\right)=E\left(\omega_{i t}+u_{i t} \mid \omega_{i t-1}\right)
$$

We estimated the conditional expectation $E\left(\omega_{\mathrm{it}} \mid \omega_{\mathrm{it}-1}\right)$ using equation (15).

$$
\hat{\omega}_{i t}+u_{i t}=\hat{\varphi}_{i t}+\hat{\varphi}_{i t-1}
$$

where

$$
\begin{aligned}
\hat{\omega}_{i t}+u_{i t} & =y_{i t}-\hat{\beta} l_{i t}-\delta e n_{i t}-\hat{\alpha} k_{i t}-\hat{\gamma} r m_{i t} \\
\hat{\omega}_{i t-1} & =\varphi_{i t}\left(r m_{i t}, k_{i t-1}\right)-\hat{\alpha} k_{i t}-\hat{\gamma} r m_{i t}
\end{aligned}
$$

Now, TFP can be expressed as:

$$
\hat{\omega}_{i t}+u_{i t}=y_{i t}-\alpha k_{i t}-\beta l_{i t}-\gamma m_{i t}-\delta e n_{i t}+u_{i t}=a_{i t}
$$

where $a_{\text {it }}$ is TFP estimated by combining the estimated intermediate inputs proxy function $\phi_{i, t}($.$) , that is,$

$$
\hat{\omega}_{i t}=\hat{\varphi}_{i t}\left(m_{i t}, k_{i t}\right)-\hat{\gamma} m_{i t}-\hat{\alpha} k_{i t}
$$

After estimating TFP, we investigate the impact of corporate tax, trade liberalization and R\&D on firm-level TFP using the following model;

$$
T F P_{i t}=f\left(C R T_{i t}, T L_{i t}, R \& D_{i t}\right)
$$


where CRT, TL and R\&D are corporate tax, trade liberalization and research and development respectively. Equation (19) can be written in a testable form as;

$$
T F P_{i t}=\beta_{0}+\beta_{\mathrm{CRT}} C R T_{i t}+\beta_{\mathrm{TL}} T L_{i t}+\beta_{\mathrm{RD}} R \& D_{i t}+\varepsilon_{i t}
$$

After incorporating trade liberalization proxies that is, average tariff rate (AVT), custom duty (CD) and sales tax (ST), equation (20) takes the following form;

$$
\begin{aligned}
T F P_{i t}=\beta_{0} & +\beta_{\mathrm{CRT}} C R T_{i t}+\beta_{\mathrm{AVT}} A V T_{i t}+\beta_{\mathrm{CD}} C D_{i t}+\beta_{\mathrm{ST}} S T_{i t} \\
& +\beta_{\mathrm{R} \& \mathrm{D}} R \& D_{i t}+\varepsilon_{i t}
\end{aligned}
$$

We expect that trade liberalization and R\&D would exert positive impact on TFP growth while higher corporate tax is likely to have negative effect.

\section{Results and Discussion}

Table 1 (Panel A) provides descriptive statistics. It can be seen from Table 1 (panel A) that mean values of all the variables are positive. Firms output $\left(\mathrm{y}_{\mathrm{it}}\right)$ has the highest mean value of 8.297 , followed by energy (8.153), capital stock (7.365), raw material (7.002) and labour force (5.466). The positive mean values of capital stock, labour force, raw material and energy indicates pivotal role of these factors in industrial productivity in Pakistan.

Besides, we observed high volatility in the data as indicated by the values of standard deviation. The possible reason of this could be the heterogeneous characteristics of sampled firms. Raw material is relatively more volatile as compared to other factors, showing that the prices of raw material are fluctuating over time. All the variables are negatively skewed and leptokurtic as indicated by the value of skewness and kurtosis. The Jarque-Bera statistics shows that variables are not normally distributed.

Panel B of Table 1 depicts correlation among the variables. All the variables are positively correlated to each other. However, en ${ }_{i t}$ have strong correlation coefficient of 0.918 with $\mathrm{y}_{i t}$, followed by $\mathrm{k}_{i t}(0.708), 1_{i t}(0.677)$, and $\mathrm{rm}_{\mathrm{it}}$ (0.449). The independent variables are also positively correlated and the correlation coefficients are less than 0.750

\begin{tabular}{|c|c|c|c|c|c|}
\hline Panel A: & $y_{i t}$ & $\mathrm{rm}_{\mathrm{it}}$ & $k_{i t}$ & $\mathrm{I}_{\text {it }}$ & $e_{\text {it }}$ \\
\hline Mean & 8.297 & 7.002 & 7.365 & 5.466 & 8.153 \\
\hline Maximum & 13.625 & 12.713 & 12.424 & 10.190 & 13.603 \\
\hline Minimum & 0.900 & 1.231 & 4.993 & 1.396 & 0.000 \\
\hline Std. Dev. & 1.497 & 2.210 & 1.703 & 1.565 & 1.568 \\
\hline Skewness & -0.126 & -1.517 & -0.782 & -1.066 & -0.651 \\
\hline Kurtosis & 5.636 & 6.310 & 6.994 & 6.038 & 7.939 \\
\hline Jarque-Bera & $785.190^{*}$ & $2257.270^{*}$ & $2060.570^{*}$ & $1542.330^{*}$ & $2920.740^{*}$ \\
\hline \multicolumn{6}{|c|}{ Panel B: correlation analysis } \\
\hline \multicolumn{6}{|l|}{ Variable } \\
\hline$y_{i t}$ & 1.000 & & & & \\
\hline $\mathrm{rm}_{\mathrm{it}}$ & 0.449 & 1.000 & & & \\
\hline $\mathrm{k}_{\mathrm{i}, \mathrm{t}}$ & 0.708 & 0.278 & 1.000 & & \\
\hline $\mathrm{I}_{\text {it }}$ & 0.677 & 0.356 & 0.511 & 1.000 & \\
\hline $\mathrm{en}_{\mathrm{it}}$ & 0.918 & 0.515 & 0.647 & 0.721 & 1.000 \\
\hline
\end{tabular}
in each case.

Table 1: Descriptive statistics and correlation analysis

Source: Authors own calculation. * indicate significance at the $1 \%$ level of significance. 
Usman Shaukat KHAN, Muhammad Arshad KHAN, Saima NAWAZ, Abdul RAHMAN /

\subsection{Estimation of Production Function}

In the first stage, the Cobb-Douglas production function specified by equation (6) was estimated using the Pooled Least Squares (PLS) method and results are reported in Table 2 (column 1). However, the major problem with PLS method is that it denies heterogeneity and individuality that may exist across different cross-sectional units. The results of PLS are, therefore, inefficient due to the presence of serial correlation and non-normality of residuals as indicated by Durbin-Watson and Jarque-Bera statistics. We, therefore, estimated equation (6) by employing the FE and RE models and results are displayed in Table 2 (columns2-3). We choose the RE model as the p-value associated to Hausman statistic is greater than 0.05 , which provides an indication of the acceptance of the null hypothesis. This means that RE model is more reliable and efficient than FE model. However, the performance of PLS, FE and RE models are not good because the estimated residuals are serially correlated and nonnormal. Furthermore, PLS, FE and RE models do not capture the endogeneity and heteroscedasticity issues. Because of the presence of potential endogeneity and serial correlation, we adopt the dynamic System Generalized Method of Moment (Sys-GMM) approach to handle endogeneity and serial correlation issues (Hsiao, 2003). The Sys-GMM estimator developed by Blundell and Bond (1998) uses lagged levels as instruments for equations in first differences. The SysGMM is more appropriate since it combines equations in first differences with instruments in levels. The results based on the two-step Sys-GMM are reported in column 4 of Table 2. The Hansen J-test validates the GMM instruments. We also found no evidence of second order autocorrelation in the estimated residuals as indicated by the insignificance of the $\mathrm{AR}_{2}$ test. To avoid heteroscedasticity, we used White's corrected standard errors of the coefficients. The SysGMM estimation results are asymptotically more efficient (Windmeijer, 2000).

The results presented in column 4 of Table 2 are statistically significant at $1 \%$ level of significance. All the coefficients have positive sign and statistically significant except for the coefficient of physical capital stock. It can be seen from the results that coefficient of lagged productivity $\left(y_{i t-1}\right)$ exerts positive impact on $y_{i t}$ in the current period. The estimated coefficient indicates that a $1 \%$ increase in industrial productivity in the previous period increases current period productivity by $0.207 \%$. This supports the presence of inertia in the adjustment process and takes four years for full convergence. The industrial capital $\left(\mathrm{k}_{\mathrm{it}}\right)$ exerts significant negative impact on firm-level productivity, indicating that a $1 \%$ increase in physical capital stock lead to reduce industrial productivity by $0.082 \%$ in the short-run. One reason of this finding could be inefficient allocation of capital resources in industrial sector in Pakistan. The other reason could be that most firms are using obsolete plants and machinery in production process, which adversely affected firm's productivity in Pakistan. Another reason could be more use of unskilled labor force instead of updated plant and machinery, and advanced technology in production processes. These results are in line with those of Burki and Khan (2004), Ghosh (2013), Ahmed, Khan, Mahmood, and Afzal (2017), MohebAlizadeh and Handfield (2018) and Bournakis and Mallick (2018). The coefficient of industrial labor is 0.003 which shows that labor force exerts significant positive impact on firm-level productivity. This suggests that a $1 \%$ increase in labor input $\left(1_{\mathrm{it}}\right)$ increases firm-level productivity by $0.003 \%$. The small coefficient of industrial labor is astonishing but not unusual for labour intensive country like Pakistan. The main reason of this finding could be unskilled labour force engaged in industrial sector and low wage rate.

The coefficients of raw material $\left(\mathrm{rm}_{\mathrm{it}}\right)$ and energy $\left(\mathrm{en}_{\mathrm{it}}\right)$ inputs indicate significant positive impact on firm-level productivity. The results indicate that a $1 \%$ increase in $\mathrm{rm}_{\mathrm{it}}$ and $\mathrm{en}_{\mathrm{it}}$ input would enhance firms-level output by $0.034 \%$ and $1.043 \%$ respectively. Raw material is one of the basic components in industrial production process. The uninterrupted supply of raw material would increase industrial output. However, increase in the prices of raw material would increase cost of production. The small coefficient of raw material indicates either insufficient availability of quality raw material or high prices of raw material in Pakistan. These findings are consistent with those by Ghosh (2013), Ahmed, Khan, Mahmood, and Afzal (2017), Moheb-Alizadeh and Handfield (2018) and Bournakis and Mallick (2018).

Regarding energy input, the result shows that $1 \%$ increase in energy supply to industrial sector would enhance industrial output by $1.043 \%$. This finding is inconsistent with earlier findings by Burki and Khan (2004), Mehmood (2012), Shakeel, Iqbal, and Majeed (2014) and Ahmed, Khan, Mahmood, and Afzal (2017). The deviation of this finding from earlier studies could be due to energy crisis faced by Pakistan during last two decades. Unlike previous studies, we found positive impact of energy on firm-level output with relatively large coefficient. The positive and large coefficient of energy could be due to firms own captive power plants that provide uninterrupted flow of electricity clubbed with better load management against the energy crisis.

\subsection{Estimation of Firms-Level TFP}

The focus of this study is to investigate the impact of corporate tax, trade liberalization and $\mathrm{R} \& \mathrm{D}$ on firm-level TFP in case of Pakistan for the period 1997-2017. To this end, we have computed firms-level $T F P_{\text {it }}$ using equation (18). We observed that average value of TFP of the individual firms is positive with a meager magnitude, while some sampled firms also have negative $T F P_{\text {it }}$ growth. ${ }^{2}$ 
Table 2: Estimates of firm-level production function

\begin{tabular}{|c|c|c|c|c|}
\hline \multicolumn{5}{|c|}{ Dependent variable: $y_{i t}$} \\
\hline \multirow{2}{*}{ Variable } & PLS & $\mathrm{FE}$ & RE & Sys-GMM \\
\hline & 1 & 2 & 3 & 4 \\
\hline$y_{i t-1}$ & - & - & - & $\begin{array}{c}0.027^{*} \\
(48.335)\end{array}$ \\
\hline $\mathrm{rm}_{\mathrm{it}}$ & $\begin{array}{l}-0.012^{*} \\
(-2.218)\end{array}$ & $\begin{array}{c}0.003 \\
(1.406)\end{array}$ & $\begin{array}{l}0.021^{*} \\
(2.664)\end{array}$ & $\begin{array}{c}0.034^{*} \\
(17.375)\end{array}$ \\
\hline$k_{i t}$ & $\begin{array}{c}0.170^{*} \\
(20.689)\end{array}$ & $\begin{array}{l}-0.0006 \\
(-0.283)\end{array}$ & $\begin{array}{l}0.015^{* *} \\
(1.770)\end{array}$ & $\begin{array}{c}-0.082^{*} \\
(-25.147)\end{array}$ \\
\hline $\mathrm{I}_{\text {it }}$ & $\begin{array}{l}0.011^{+* *+} \\
(1.163)\end{array}$ & $\begin{array}{l}-0.003^{*} \\
(-3.099) \\
\end{array}$ & $\begin{array}{c}-0.002 \\
(-0.508) \\
\end{array}$ & $\begin{array}{l}0.003^{*} \\
(2.892) \\
\end{array}$ \\
\hline $\mathrm{en}_{\mathrm{it}}$ & $\begin{array}{c}0.759^{*} \\
(63.296)\end{array}$ & $\begin{array}{c}1.005^{\star} \\
(237.029)\end{array}$ & $\begin{array}{c}0.959^{*} \\
(42.468)\end{array}$ & $\begin{array}{c}1.043^{*} \\
(195.310)\end{array}$ \\
\hline C & $\begin{array}{c}0.886^{*} \\
(15.212)\end{array}$ & $\begin{array}{l}0.108^{*} \\
(4.236)\end{array}$ & $\begin{array}{c}0.243 \\
(1.127)\end{array}$ & - \\
\hline Adj $R^{2}$ & 0.866 & 0.998 & 0.785 & - \\
\hline $\begin{array}{l}\text { Durbin-Watson } \\
\text { Test }\end{array}$ & 0.187 & 1.010 & 0.476 & - \\
\hline Normality Test & $902110.7[0.000]^{*}$ & $98.52[0.000]^{*}$ & $2704613[0.000]^{*}$ & - \\
\hline Hausman Test & - & & $0.00[1.000]$ & - \\
\hline Hansen's J-Test & - & - & - & $133.002[0.274]$ \\
\hline $\mathrm{AR}_{1}$ & - & - & - & $-2.98[0.003]^{* *}$ \\
\hline $\mathrm{AR}_{2}$ & - & - & - & $0.225[0.822]$ \\
\hline
\end{tabular}

Note: (.) indicate t-statistics, while ${ }^{*},{ }^{* *}$ and ${ }^{* * *}$ represents significance at the $1 \%, 5 \%$ and $10 \%$ level of significance respectively. PLS, FE, $\mathrm{RE}$ and Sys-GMM indicates the panel least square method, fixed effects model, random effects model and system-generalized method of moment, while $\mathrm{AR}_{1}$ and $\mathrm{AR}_{2}$ are Arellano and Bond (1991) test for first order and second order serial correlation. We have used differenced equation with levels instruments, estimation also include time dummies. Figure in [.] are the p-value.

\subsection{Impact of Corporate Tax, Trade Liberalization and Research and Development on Firm-Level TFP}

Panel A and Panel B of Table 3 shows summary statistics and correlation analysis of TFP and other variables under investigation. It is evident from Table 3 (panel A) that mean of all variables is positive. The mean value of TFP is 0.013 with maximum of 4.03 which corresponds to textile firm, while minimum TFP value is -2.714 which is also related to textile firm.

The estimated TFP shows greater volatility as evident by the higher value of standard deviation that is, 0.311. Except for ST, all variables are positively skewed, while value of kurtosis is greater than 3 , indicating that data is non-normal.
This result is also confirmed by the significance of JarqueBera statistics. The correlation analysis (Panel B of Table 3) depicts that trade liberalization proxied by average tariff rate, customs duty and sales tax are negatively correlated with TFP. Likewise, corporate tax and R\&D also show negative correlation with TFP.

Table 4 depicts the results with respect to the impact of corporate tax, trade liberalization and R\&D on TFP. The estimates based on the sys-GMM estimator are more appropriate than other models. The results of the sys-GMM are efficient because there is no problem of endogeneity and heteroscedasticity as indicated by the p-value of $\mathrm{AR}_{2}$. Furthermore, insignificance of Hansen's J-statistic also indicates the validity of selected instruments. 
Usman Shaukat KHAN, Muhammad Arshad KHAN, Saima NAWAZ, Abdul RAHMAN /

Table 3: Descriptive statistics and correlation analysis

\begin{tabular}{|c|c|c|c|c|c|c|}
\hline Panel A & TFP & AVT & $C D$ & ST & CRT & R\&D \\
\hline Mean & 0.013 & 0.133 & 0.411 & 0.147 & 0.360 & 0.019 \\
\hline Maximum & 4.304 & 0.510 & 1.707 & 0.510 & 0.460 & 1.000 \\
\hline Minimum & -2.714 & 0.000 & 0.052 & 0.000 & 0.310 & 0.000 \\
\hline Std. Dev. & 0.311 & 0.037 & 0.499 & 0.042 & 0.040 & 0.137 \\
\hline Skewness & 6.101 & 8.187 & 1.060 & -0.698 & 1.534 & 7.018 \\
\hline Kurtosis & 85.806 & 77.802 & 2.817 & 22.021 & 4.234 & 50.247 \\
\hline Jarque-Bera & $670798.100^{*}$ & $561428.700^{*}$ & $433.592^{*}$ & $34829.860^{*}$ & $1047.542^{*}$ & $232600.400^{\circ}$ \\
\hline P-value & 0.000 & 0.000 & 0.000 & 0.000 & 0.000 & 0.000 \\
\hline \multicolumn{7}{|l|}{ Panel B } \\
\hline TFP & 1.000 & & & & & \\
\hline AVT & -0.016 & 1.000 & & & & \\
\hline$C D$ & -0.00 & 0.198 & 1.000 & & & \\
\hline ST & -0.096 & 0.003 & -0.388 & 1.000 & & \\
\hline CRT & -0.020 & 0.170 & 0.697 & -0.337 & 1.000 & \\
\hline R\&D & -0.047 & -0.027 & 0.061 & -0.157 & 0.044 & 1.000 \\
\hline
\end{tabular}

Source: Author's own calculation. * indicate significance at the $1 \%$ level of significance.

The results presented in Table 4 are statistically significant at $1 \%$ level of significance. The one year lagged coefficient of TFP exerts significant positive impact on TFP in the current period. The estimated coefficient indicates that $1 \%$ increase in the previous period's TFP increases current TFP by $0.081 \%$. This supports the presence of inertia in the adjustment process and it takes around ten years for full convergence. The estimated coefficients of average tariff rate $\left(\mathrm{AVT}_{\mathrm{it}}\right)$ sales tax $\left(\mathrm{ST}_{\mathrm{it}}\right)$ and corporate tax $\left(\mathrm{CRT}_{\mathrm{it}}\right)$ are negatively signed and statistically significant at $1 \%$ level of significance. The negative coefficients for $\mathrm{AVT}_{\text {it }}$ and $\mathrm{ST}_{\text {it }}$ suggest that a $1 \%$ decrease in $\mathrm{AVT}_{\mathrm{it}}$ and $\mathrm{ST}_{\mathrm{it}}$ would increase TFP by 0.249 and 0.716 percentage points respectively. The main reason of this increase could be the reduction in average tariff rate on imports by the Government of Pakistan (GoP) from $51 \%$ in 1997 to around $12 \%$ in 2017. This enabled manufacturing firms to import quality raw material and high-tech machinery, which in turn increases TFP due to reduction in input costs. Moreover, reduction in tariff barriers also encourages transfer of technology which allows industrial firms to adopt efficient production techniques. These findings are consistent with Golder and Kumari (2003), Yu (2010), Topalova and Khandelwal (2011), Jiang (2014) and Ahmed, Khan, Mahmood and Afzal (2017).

With regard to the impact of corporate tax (CRT) as a measure of fiscal policy, the result reveals that a reduction in CRT exerts significant positive impact on firm-level TFP. The results show that a $1 \%$ reduction in corporate tax rate would increase firm-level TFP by $0.763 \%$. This finding is consistent with theoretical prediction that reduction in corporate tax can have positive impact on TFP (Arlen \& Weiss, 1995). In fact, the GoP gradually reduced corporate tax from $46 \%$ in 1997 to $31 \%$ in 2017, which reflected positive impact on firm-level TFP. Bournakis and Mallick (2018) found similar results in case of United Kingdom firms. They concluded that increase in corporate tax liability decreases firms-level productivity because higher rate of statuary taxes increases the cost of capital which adversely affects investment decision.

The coefficient of customs duty (0.091) is unusual as earlier studies reported negative coefficient of trade liberalization (for instance, Ahmed, Khan, Mahmood, \& Afzal, 2017, Bournakis $\&$ Mallick, 2018). This deviation could be due to decline in export of sampled firms. Moreover, our sample consists of both the exporting and non-exporting firms and customs duty is higher in case of domestic consumption and lower in case of exports. Hence, overall impact of customs duty appears to be negative at industrial firm-level despite of reduction in rate of customs duty. There has been gradual reduction in rate of customs duty from $170 \%$ to $8.5 \%$ over the period of 1997 to 2017 in Pakistan. We deduce that reduction in rate of customs duty encourages transfer of technology through import of modern plant and machinery exerting positive impact on TFP. Therefore, our findings confirm theoretical assertions that reduction in tariff barriers would exert positive impact on TFP growth (Samuelson, 1948; Helpman\& Krugman, 1985; Aghion, Bloom, Blundell, Griffith, \& Howitt, 2005). 
Table 4: Impact of TL, CRT and R\&D on TFP

\begin{tabular}{|c|c|}
\hline \multicolumn{2}{|c|}{ Dependent variable: $T F P_{i t}$} \\
\hline Variable & Sys-GMM \\
\hline TFP $_{i t-1}$ & $0.081^{*}(395.120)$ \\
\hline $\mathrm{AVT}_{i t}$ & $-0.259^{*}(16.893)$ \\
\hline $\mathrm{CD}_{i t}$ & $0.091^{*}(128.661)$ \\
\hline $\mathrm{ST}_{i t}$ & $-0.716^{*}(-54.026)$ \\
\hline $\mathrm{CRT}_{i t}$ & $-0.491^{*}(-93.082)$ \\
\hline $\mathrm{R} \& \mathrm{D}_{i t}$ & $-10.046^{*}(-14.545)$ \\
\hline J-Test & $145.981[0.392]$ \\
\hline $\mathrm{AR}_{1}$ & $-2.16[0.030]^{* * *}$ \\
\hline $\mathrm{AR}_{2}$ & $0.545[0.586]$ \\
\hline
\end{tabular}

Note: (.) indicate t-statistics, while * and ${ }^{* * *}$ represents significance at the $1 \%$ and $10 \%$ level of significance respectively. PLS, FE, $\mathrm{RE}$ and Sys-GMM indicates the panel least square method, fixed effects model, random effects model and system-generalized method of moment, while $\mathrm{AR}_{1}$ and $\mathrm{AR}_{2}$ are Arellano and Bond (1991) test for first order and second order serial correlation. We have used differenced equation with levels instruments. Figures in [.] are the p-value.

Regarding the impact of research and development (R\&D) on TFP, our results indicate significant negative impact. This implies that firms are not investing in knowledge-based assets. This could be mainly due to imposition of higher level of taxes that may restrict manufacturing firms to undertake R\&D projects. Bournakis and Mallick (2018) argued that higher level of tax liability weakens the borrowing capacity of manufacturing firms that invest in innovation which may discourage the generation of new knowledge.

\section{Conclusion, Policy Implication and Limitation}

This study examines the impact of corporate tax as a measure of fiscal policy, trade liberalization, and research and development on TFP by considering 153 industrial firms listed on Pakistan Stock Exchange over the period from 1997 to 2017. Following Bournakis and Mallick (2018), we have used the Sys-GMM to address the issues of endogeneity and sample selection bias. The results indicate that trade liberalization promotes TFP growth through technology infusion, knowledge dissemination and supply of highquality raw material. Therefore, further reduction in tariff barriers would enhance firm-level TFP of industrial sector in Pakistan through production of high-quality goods.

However, one of the consequences of trade liberalization is that it reduces government revenue in developing countries like Pakistan which can create fiscal imbalances. To contain fiscal imbalances, the GoP usually imposes corporate tax. Thus, we considered the impact of this aspect of fiscal policy on the firm-level TFP in Pakistan. The results indicate that higher level of corporate tax exerted significant negative impact on firm-level TFP. Thus, firms have to pay higher tax on net income and ultimately left with lower retained earnings. This exerted negative impact on firm's performance, which retards future economic growth as firms have lower amount to capitalize in subsequent periods. The higher corporate tax also increases cost of capital. Hence, if TFP is entrenched in capital goods, the increase in corporate tax rate would discourage investment that causes decline in TFP.

This study offers some important policy implications. Firstly, trade liberalization may enhance efficient use of capital resources which in turn lead to eliminate industrial inefficiencies at firm-level in Pakistan. The reduction in average tariff rate and customs duty would significantly enhance TFP. Therefore, further reduction in tariff barriers would accelerate industrial productivity and enhance exports potential in Pakistan. The higher rate of corporate tax increases cost of capital and discourages firms from investing in tangible fixed assets such as R\&D activities which are the main source of innovations for TFP growth. Therefore, GoP may frame tax reform policies that could improve the fiscal convergence through further reduction in corporate tax rate and encourage new capital investment.

Although the present study examined the impact of corporate tax, trade liberalization and R\&D on TFP. However, the main limitation of this study is that it did not consider private-owned firms at micro-level. In future researcher may consider private owned firms at micro-level. Besides, nonlisted family firms may also be investigated to examine the impact of family-ownership on TFP growth. Additionally, future researcher may investigate the impact of fiscal policy on TFP by considering cross-section dependence and common correlated estimator (CCE).

\section{References}

Abramovitz, M. (1956). Resource and output trends in the United States since 1870. National Bureau of Economic Research Occasional Paper 52, 1-23. https://www.nber.org/chapters/ c5650.pdf

Ackerberg, D. A., Caves, K., \& Frazer, G. (2015). Identification properties of recent production function estimators. Econometrica, 83(6), 2411-2451.

Aghion, P., \& Howitt, P. (2006). Appropriate growth policy: A unifying framework. Journal of the European Economic Association, 4(2-3), 269-314.

Aghion, P., Bloom, N., Blundell, R., Griffith, R., \& Howitt, P. (2005). Competition and innovation: An inverted-U relationship. The Quarterly Journal of Economics, 120(2), 701728. DOI: $10.2307 / 25098750$ 
Usman Shaukat KHAN, Muhammad Arshad KHAN, Saima NAWAZ, Abdul RAHMAN /

Journal of Asian Finance, Economics and Business Vol 7 No 10 (2020) 555-569

Ahmed, G., Khan, M. A., \& Afzal, M. (2017). Trade liberalization and industrial productivity: Evidence from Pakistan. The Pakistan Development Review, 56(4), 319-348.

Alimi, R. S. (2015). Financial deepening and economic growth: A system GMM panel analysis with application to 7 SSA countries. MPRA Working Paper No. 65789. Available at https:// mpra.ub.uni-muenchen.de/65789/1/MPRA_paper_65789.pdf

Arellano, M., \& Bond, S. (1991). Some tests of specification for panel data: Monte Carlo evidence and an application to employment equations. The Review of Economic Studies, 58(2), 277-297.

Bloom, N., \& van Reenen, J. (2010). Why do management practices differ across firms and countries? Journal of Economic Perspectives, 24(1), 203-24.

Blundell, R., \& Bond, S. (1998). Initial conditions and moment restrictions in dynamic panel data models. Journal of Econometrics, 87(1), 115-143.

Bournakis, I., \& Mallick, S. (2018). TFP estimation at firm level: The fiscal aspect of productivity convergence in the UK. Economic Modelling, 70, 579-590.

Bravo-Biosca, A., Criscuolo, C., \& Menon, C. (2016). What drives the dynamics of business growth? Economic Policy, 31(88), 703-742.

Brekke, K. R., Garcia Pires, A. J., Schindler, D., \&Schjelderup, G. (2014). Capital taxation and imperfect competition: ACE vs. CBIT. NHH Department of Economics Discussion Paper No. 32. NHH Department of Economics.

Burki, A. A., \& Khan, M.H. (2004). Effects of allocative inefficiencies in resource allocation and energy substitution in Pakistan's manufacturing. Energy Economics, 26, 371-388.

Chaudhry, A. (2009). Total factor productivity growth in Pakistan: An analysis of the agricultural and manufacturing sectors. The Lahore Journal of Economics, 14, 1-16.

Del Gatto, M., Di Liberto, A., \&Petraglia, C. (2011). Measuring productivity. Journal of Economic Surveys, 25(5), 952-1008.

Denison, E. F. (1962). Education, economic growth, and gaps in information. Journal of Political Economy, 70, 124-124.

Devereux, M. P., \& Griffith, R. (2003). Evaluating tax policy for location decisions. International Tax and Public Finance, 10, 107-126.

Dischinger, M., \& Nadine, R., (2011). Corporate taxes and the location of intangible assets within multinational firms. Journal of Public Economics, 95(7), 691-707.

Djankov, S., Ganser, T., McLiesh, C., Ramalho, R., \& Shleifer, A. (2010). The effect of corporate taxes on investment and entrepreneurship. American Economic Journal: Macroeconomics, 2(3), 31-64.

Eaton, J., Kortum, S., \&Kramarz, F. (2011). An anatomy of international trade: Evidence from French firms. Econometrica, 79(5), 1453-1498.

Eberhardt, M., \& Christian, H. (2010). Untested assumptions and data slicing: A critical review of firm-level production function estimators. Department of Economics Discussion Paper No. 513. Oxford University

Fernandes, A. M. (2007). Trade policy, trade volumes and plantlevel productivity in Colombian manufacturing industries. Journal of International Economics, 71(1), 52-71.

Fulginiti, L. E., Perrin, R. K., \& Yu, B. (2004). Institutions and agricultural productivity in Sub-Saharan Africa. Agricultural Economics, 31(2-3), 169-180.

Fullerton, D. (1987). The indexation of interest, depreciation, and capital gains and tax reform in the United States. Journal of Public Economics,32(1), 25-51.

Gentry, W. M., \& Glenn, H. R. (1998). Fundamental tax reform and corporate financial policy. Tax Policy and the Economy, 12,191-227.

Ghosh, S. (2013). Do economic reforms matter for manufacturing productivity? Evidence from the Indian experience. Economic Modelling, 31, 723-733.

Golder, B., \& Kumara, A. (2003). Import liberalisation and productivity growth in Indian manufacturing in the 1990s. Developing Economies, 41(4), 436-60.

Gorg, H., \&Spaliara, M. E. (2014). Exporters in the financial crises. National Institute Economic Review, 228(1), R49-R57.

Hall, B., \& Van Reenen, J., (2000). How effective are fiscal incentives for R\&D? A review of the evidence. Research Policy, 29(4-5), 449-469.

Hall, J., \& Scobie, G. M. (2006). The role of R\&D in productivity growth: The case of agriculture in New Zealand: 1927 to 2001. New Zealand treasury working paper No. 06/01. New Zealand Treasury.

Hall, R. E., \& Jones, C. I. (1999). Why do some countries produce so much more output per worker than others? The Quarterly Journal of Economics, 114(1), 83-116.

Helpman, E., \& Krugman, P. (1985). Market structure and foreign trade: Increasing returns, imperfect competition, and the international economy. Cambridge, MA: MIT Press.

Hsiao, C. (2003). Analysis of panel data. New York, NY: Cambridge University Press.

Hsieh, C. T., \&Klenow, P. J. (2009). Misallocation and manufacturing TFP in China and India. The Quarterly Journal of Economics, 124(4), 1403-1448.

Javorcik, B.S., \&Spatareanu, M. (2008). To share or not to share: Does local participation matter for spillovers from foreign direct investment. Journal of Development Economics, 85 (1-2), 194-217.

Jiang, Y.F. (2014). The effect of VAT on total factor productivity in China-based on the one-step Estimation Method. In: 2014 International Conference on Management Science and Management Innovation (MSMI 2014) (pp. 247-253).Atlantis Press.

Kasahara, H., \& Lapham, B. (2013). Productivity and the decision to import and export: Theory and evidence. Journal of international Economics, 89(2), 297-316. 
Katayama, H., Lu, S. \&Tybout, J. R. (2009). Firm-level productivity studies: illusions and a solution. International Journal of Industrial Organization, 27(3), 403-413.

Khan, M. A. \& Ahmed, A. (2012). Modeling trade, investment, growth and liberalisation: case study of Pakistan. The Pakistan Development Review, 51(4), 187-208.

Khan, M. A. \& Qayyum, A. (2007). Trade liberalisation, financial development and economic growth. PIDE Working Papers 19, Pakistan Institute of Development Economics Islamabad.

Khan, M. A., \& Ahmed, A. (2012). Modeling trade, investment, growth and liberalization: Case study of Pakistan. The Pakistan Development Review, 51(4), 187-208.

Kim, Y. E., Loayza, N. V., \&Balcazar, C. M. (2016). Productivity as the key to economic growth and development. World Bank Research and Policy Briefs No. 108092. Washington, DC: World Bank.

Konings, J., \&Vandenbussche, H. (2013). Antidumping protection hurts exporters: firm-level evidence. Review of World Economics, 149(2), 295-320.

Kuznets, S. (1966). Modern economic growth: Rate, structure and spread. New Haven, CT: Yale University Press.

Levinsohn, J., \&Petrin, A. (2003). Estimating production functions using inputs to control for unobservables. The Review of Economic Studies, 70(2), 317-341.

Lucas, R. (1990). Supply-side economics: An analytical review. Oxford Economic Papers, 42(2), 293-316.

Manez, J. A., Rochina-Barrachina, M. E., Sanchis-Lopis, J. A., \& Vicente, O. (2014). Financial constraints and R\&D and exporting strategies for Spanish manufacturing firms. Industrial and Corporate Change, 23(6), 1563-1594.

Melitz, M. J. (2003). The impact of trade on intra-industry reallocations and aggregate industry productivity. Econometrica, 71(6), 1695-1725.

Moheb-Alizadeh, H., \& Handfield, R. (2018). The Impact of raw materials price volatility on cost of goods sold (COGS) for product manufacturing. IEEE Transactions on Engineering Management, 65(3), 460-473.

Olley, G. S., \&Pakes, A. (1996). The dynamics of productivity in the telecommunications equipment industry. Econometrica, 64(6), 1263-1297.
Pavcnik, N. (2002). Trade liberalization, exit, and productivity improvements: Evidence from Chilean plants. The Review of Economic Studies, 69(1), 245-276.

Samuelson, P. (1948). International trade and equalization of factor price. The Economic Journal, 58(230), 163-184.

Sehgal, S., \& Sharma, S. (2012). Total factor productivity of manufacturing sector in India: A regional analysis for the state of Haryana. Economic Journal of Development Issues, 13, 97-118.

Shakeel, M., Iqbal, M., \& Majeed, M. (2014). Energy consumption, trade and GDP: A Case Study of South Asian countries. The Pakistan Development Review, 53, 461-476.

Sheikh, S. A., \& Ahmed, S. (2011). Impact of trade liberalisation and domestic economic reforms on technical efficiency of agrobased industries in Pakistan. International Journal of Business and Social Sciences, 2(33), 219-226.

Solow, R. M. (1956). A contribution to the theory of economic growth. The Quarterly Journal of Economics, 70(1), 65-94.

Syverson, C. (2011). What determines productivity? Journal of Economic Literature, 49(2), 326-65.

Topalova, P., \& Khandelwal, A. (2011). Trade liberalization and firm productivity: The case of India. Review of Economics and Statistics, 93(3), 995-1009.

Van Beveren, I. (2012). Total factor productivity estimation: A practical review. Journal of Economic Surveys, 26(1), 98-128.

Windmeijer, F. (2000). Efficiency comparisons for a system GMM estimator in dynamic panel data models. In: Innovations in Multivariate Statistical Analysis (pp. 175-184). Available at: https://link.springer.com/ chapter/10.1007/978-1-4615-4603-0_11

Young, A. (1992). A tale of two cities: Factor accumulation and technical change in Hong Kong and Singapore. NBER Macroeconomics Annual, 7, 13-54.

Yu, M. (2010) Trade liberalisation and productivity: Evidence from Chinese firms. Economic Research Journal, 45(12), 97-110.

Zakaria M., \& Ahmed, E. (2013). Openness-growth nexus in Pakistan: A macro-econometric analysis. Argumenta Oeconomica, 1(30), 47-83. 
Usman Shaukat KHAN, Muhammad Arshad KHAN, Saima NAWAZ, Abdul RAHMAN /

Journal of Asian Finance, Economics and Business Vol 7 No 10 (2020) 555-569

Appendix A: Listed Firms having negative average TFP over the period 1997-20171

\begin{tabular}{|c|c|c|c|}
\hline Company Name & TFP & Company Name & TFP \\
\hline Jubilee Spinning \& Weaving Mills & -0.819 & Al-Ghazi Tractors & -0.038 \\
\hline Dewan Sugar Mills & -0.358 & Pakistan Petroleum & -0.038 \\
\hline Javedan Corporation & -0.288 & Bestway Cement & -0.037 \\
\hline Pioneer Cement & -0.172 & Abbott Laboratories (Pakistan) & -0.035 \\
\hline Hinoon Laboratories & -0.159 & Pak Elektron & -0.035 \\
\hline Pakistan State Oil & -0.142 & National Refinery & -0.035 \\
\hline Ferozsons & -0.130 & Cherat Packaging & -0.034 \\
\hline Garibwal Cement & -0.109 & First Imrooz Modaraba & -0.032 \\
\hline Atlas Honda & -0.101 & Sitara Chemical Industries & -0.031 \\
\hline Merit Packaging & -0.089 & Engro Corporation & -0.031 \\
\hline Pakistan National Shipping Corporation & -0.086 & Archroma Pakistan & -0.030 \\
\hline Cherat Cement Co & -0.084 & National Foods & -0.029 \\
\hline Crescent Steel and Allied Products & -0.084 & Chashma Sugar Mills & -0.029 \\
\hline Nimir Industrial Chemicals & -0.080 & Lucky Cement & -0.029 \\
\hline Maple Leaf Cement Factory & -0.073 & Power Cement & -0.029 \\
\hline Fecto Cement & -0.072 & Tandlianwala Sugar Mills & -0.028 \\
\hline $\begin{array}{l}\text { Pakistan International Container } \\
\text { Terminal }\end{array}$ & -0.071 & Berger Paints Pakistan & -0.028 \\
\hline Pakistan Services & -0.071 & Pakistan Refinary & -0.028 \\
\hline DG Khan Cement Co & -0.069 & Ismail Industries & -0.024 \\
\hline The Searle Company & -0.069 & Colgate Pakistan & -0.024 \\
\hline Kohat Cement & -0.068 & Bata Pakistan & -0.022 \\
\hline Century Paper \& Board Mills & -0.064 & Shell Pakistan & -0.021 \\
\hline Ansari Sugar Mills & -0.062 & Dawood Hercules Corporation & -0.020 \\
\hline Elahi Cotton Mills & -0.061 & Dandot Cement Company & -0.018 \\
\hline Wah Nobel Chemicals & -0.058 & KSB Pumps & -0.016 \\
\hline Feroze1888 Mills & -0.053 & International Industries & -0.014 \\
\hline Biafo Industries & -0.052 & Rafhan Maize Product Company & -0.014 \\
\hline Fauji Cement Company & -0.051 & Dadex Eternit & -0.013 \\
\hline Mari Gas & -0.047 & Baba Farid Sugar Mills & -0.012 \\
\hline Oil and Gas Development Company & -0.046 & Hino Pak & -0.012 \\
\hline Packages & -0.043 & Artistic Denim Mills & -0.011 \\
\hline ICI Pakistan & -0.043 & Sapphire Textile Mills & -0.009 \\
\hline Service Industries & -0.042 & Mitchell's Fruit Farms & -0.005 \\
\hline sanofi-aventis Pakistan & -0.041 & Husein Sugar Mills & -0.005 \\
\hline Nestle Pakistan & -0.040 & Treet Corporation & -0.002 \\
\hline Ghani Glass & -0.039 & Sapphire Fibres & -0.020 \\
\hline Tariq Glass Industries & -0.038 & Burshane LPG (Pakistan) & -0.001 \\
\hline Waves Singer Pakistan & -0.038 & Nishat Mills & -0.002 \\
\hline
\end{tabular}


Appendix B: Listed Firms having positive Average TFP over the period 1997-2107²

\begin{tabular}{|c|c|c|c|}
\hline Company Name & TFP & Company Name & TFP \\
\hline Dynea Pakistan & 0.001 & AttockRefinary & 0.028 \\
\hline ZIL & 0.001 & Gtron Industries & 0.029 \\
\hline Tri-Pack Films & 0.001 & Habib Sugar Mills & 0.031 \\
\hline GlaxoSmithKline Pakistan & 0.002 & GOC (Pakistan) & 0.031 \\
\hline Bolan Castings & 0.003 & EcoPack & 0.032 \\
\hline Dewan Cement & 0.003 & Alnoor Sugar Mills & 0.032 \\
\hline Shahtaj Sugar Mills & 0.003 & Tata Textile Mills & 0.034 \\
\hline Gul Ahmed Textile Mills & 0.004 & Faisal Spinning Mills & 0.027 \\
\hline BannuWoollen Mills & 0.004 & Faran Sugar Mills & 0.034 \\
\hline Ghazi Fabrics International & 0.004 & Al-Abbas Sugar Mills & 0.034 \\
\hline Nishat (Chunian) & 0.004 & Balochisatn Gases & 0.036 \\
\hline Sana Industries & 0.005 & Shahmurad Sugar Mills & 0.037 \\
\hline Reliance Weaving Mills & 0.006 & Ibrahim Fibres & 0.040 \\
\hline Shadab Textile Mills & 0.007 & Pakistan Oilfields & 0.047 \\
\hline Rupali Polyester & 0.007 & Dewan Mushtaq Textile Mills & 0.049 \\
\hline Pakistan Paper Products & 0.008 & Habib-ADM & 0.057 \\
\hline Pakistan Synthetics & 0.008 & Bhanero Textile Mills & 0.058 \\
\hline Jouharbad Sugar Mills & 0.009 & Security Papers & 0.060 \\
\hline $\begin{array}{l}\text { Indus Dyeing \& Manufacturing } \\
\text { Company }\end{array}$ & 0.010 & FaujiFetilizer & 0.061 \\
\hline Pakistan Cables & 0.010 & Noon Sugar Mills & 0.061 \\
\hline The Crescent Textile Mills & 0.011 & Wyeth Pakistan & 0.063 \\
\hline Buxly Paints & 0.012 & Pakistan Engineering Company & 0.069 \\
\hline Premium Textile Mills & 0.012 & Telecard & 0.073 \\
\hline Sitara Textile Mills & 0.013 & Dewan Sugar Mills & 0.078 \\
\hline Siemens (Pakistan) Engineering Co. . & 0.013 & Quetta Textile Mills & 0.082 \\
\hline Shezan International & 0.013 & Fauji Fertilizer Company & 0.096 \\
\hline Attock Gen & 0.013 & Pakistan Oxygen & 0.106 \\
\hline Mehran Sugar Mills & 0.014 & Ghani Automobile Industries & 0.117 \\
\hline Otsuka Pakistan & 0.014 & Pakistan Telecommunication & 0.132 \\
\hline Nagina Cotton Mills & 0.015 & Chakwal Spinning Mills & 0.136 \\
\hline Island Textile Mills & 0.016 & Haseeb Waqas Sugar Mills & 0.142 \\
\hline JDW Sugar Mills & 0.018 & Gillette Pakistan & 0.167 \\
\hline Sutlaj Textile & 0.018 & Johnson \& Phillips (Pakistan) & 0.327 \\
\hline Gadoon Textile Mills & 0.020 & Dewan Khalid Textile Mills & 0.346 \\
\hline Fauji Fertilizer Bin Qasim & 0.024 & Dawood Lawrencepur & 0.355 \\
\hline Salfi Textile Mills & 0.024 & Dewan Textile Mills & 0.463 \\
\hline Kohinoor Mills & 0.025 & Clover Pakistan & 0.678 \\
\hline Reliance Cotton Spinning Mills & 0.025 & Al-Abbas Sugar Mills & 2.637 \\
\hline
\end{tabular}




\section{Endnotes}

${ }^{1}$ Trade liberalization is the dismantling of tariff and non-tariff barriers to promote free trade (Ahmed, Khan, Mahmood \& Afzal, 2017).

${ }^{2}$ See Appendixes A and B 